\section{Screening test for an automated protein-bound iodine technique}

\author{
S. G. WELSHMAN AND G. MCKEE From The Lab- \\ oratories, Belfast City Hospital, Belfast
}

An automated method for the estimation of serum protein-bound iodine following alkaline incineration has been described by Welshman, Bell, and McKee (1966). In this procedure, the serum was pretreated with an anion exchange resin which removes relatively large amounts of inorganic iodine. However, organic iodine from $x$-ray contrast media was not absorbed by the resin and remained a frequent source of iodine contamination during incineration. This paper describes a simple screening test for the detection of sera containing grossly raised iodine levels. Two drops of serum are used for this test which is performed without delaying the routine protein-bound iodine estimation.

\section{PROCEDURE}

The apparatus and reagents are the same as described by Welshman et al. (1966) except that $12 \times 100 \mathrm{~mm}$ Pyrex test tubes $M / W$ are used in place of the larger tubes.

The procedure can be carried out while the normal routine batch is drying in the $115^{\circ} \mathrm{C}$ oven.

Place two drops of serum and two drops of $2 \mathrm{~N}$ potassium hydroxide in a Pyrex test tube and dry in an oven at $115^{\circ} \mathrm{C}$ for 90 minutes. Transfer the tubes to the muffle furnace and incinerate at $620^{\circ} \mathrm{C}$ for 30 minutes. When the tubes are cool add three drops of acid diluent, three drops of sodium arsenite solution, and three drops of ceric ammonium sulphate solution. Shake the tubes after the addition of each reagent. Place the tubes in a water bath at $37^{\circ} \mathrm{C}$ and after five minutes add one drop of $1 \%$ aqueous brucine sulphate solution to stop the reaction as recommended by Faulkner, Levy, and Leonards (1961).

\section{INTERPRETATION OF RESULTS}

Serum containing less than $20 \mu \mathrm{g}$ of iodine per $100 \mathrm{ml}$ will produce a definite amber coloured solution while serum with a level greater than $30 \mu \mathrm{g} / 100 \mathrm{ml}$ will give a completely colourless solution. The test may be adjusted to give greater sensitivity by prolonging the period of incubation. Contaminated serum detected by this procedure can be removed from the main batch before incineration.

The screening technique has been used in this laboratory for almost a year and has successfully detected all serum with grossly abnormal iodine levels. As approximately $3 \%$ of all sera received for protein-bound iodine estimation were contaminated with organic iodine the screening procedure has prevented numerous batches

Received for publication 18 December 1967.

\section{Stability of papain-cysteine-anti-D mixture on freeze drying and on storage}

\author{
G. M. TODD From the Glasgow and West of \\ Scotland Blood Transfusion Service
}

Papain-cysteine solution has been used at the Glasgow and West of Scotland Blood Transfusion Service since the publication by Löw (1955) on the value of activated papain solution for red cell grouping.

Gilbey and Lindars (1962) investigated the stability of freeze-dried, activated papain and found promising results. That publication prompts this report on storage of a dried papain-cysteine-anti-D mixture over a period of 10 years.

A mixture of equal parts of Löw's papain-cysteine solution and a serum containing incomplete anti-D antibody was prepared in April 1957. The serum had been tested by Löw's technique against a panel of cells of known $\mathrm{Rh}$ phenotype to ensure specificity, particularly the absence of anti-C and anti-E. The titre of the serum was 16 and of the mixture was 8 when measured by the albumin replacement technique with $\mathrm{CCDE}$ phenotyped red cells. A simple titration with saline as diluent was not suitable because only the first tube of the serial dilutions contained adequate papain for agglutination of red cells suspended in saline. The mixture was immediately distributed into ampoules in $2 \mathrm{ml}$ volumes and freeze drying was carried out with an Edwards 3 P.S. centrifugal freeze drier. The ampoules were sealed off in vacuo and stored in a metal box at room temperature $\left(20^{\circ} \mathrm{C}\right)$.

Periodically, over the years, an ampoule was opened and the contents were dissolved in $2 \mathrm{ml}$ of sterile distilled water. The approximate time of solution was noted and the mixture was then tested against a panel of six phenotyped red cell suspensions (probable genotypes $R_{1} r$, $R_{2} r, R_{1} R_{2}, R^{\prime} r, R^{\prime \prime} r$, and $r r$ ) in saline, using one drop, of red cell suspension to one drop of papain-cysteineserum mixture. Complete agglutination resulted with D-positive cells after incubation at $37^{\circ} \mathrm{C}$ for one hour and cells lacking the $\mathrm{D}$-antigen showed no agglutination.

Received for publication 25 October 1967

Screening test for an automatic protein-bound iodine technique-concluded.

of serum protein-bound iodine results from being rendered worthless.

\section{REFERENCES}

Faulkner, L. W., Levy, R. P., and Leonards, J. R. (1961). Clin. Chein., $7,637$.

Welshman, S. G., Bell, J. F., and McKee, G. (1966). J. clin. Path. $19,510$. 